
prognosis and inhibits cell proliferation and invasion through the $\mathrm{Wnt} / \beta$-catenin signaling pathway in breast cancer

This article was published in the following Dove Press journal: OncoTargets and Therapy

Hongfan Yuan, ${ }^{1,2}$ Yi Qin, ${ }^{1,2}$ Beilei Zeng, ${ }^{1,2}$ Yixiao Feng, ${ }^{1,2}$ Yunhai Li, ${ }^{1,2}$ Tingxiu Xiang,' Guosheng Ren ${ }^{1,2}$

'Chongqing Key Laboratory of Molecular Oncology and Epigenetics, The First Affiliated Hospital of Chongqing Medical University, Chongqing, People's Republic of China; ${ }^{2}$ Department of Endocrine and Breast Surgery, The First Affiliated Hospital of Chongqing Medical University, Chongqing, People's Republic of China

\section{Video abstract}

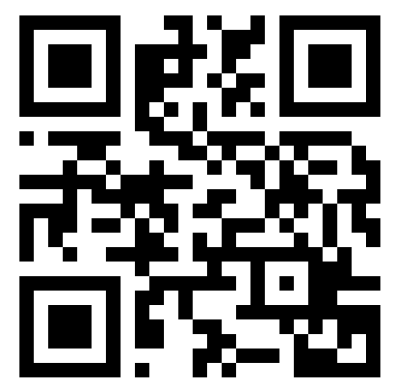

Point your SmartPhone at the code above. If you have a QR code reader the video abstract will appear. Or use: https://youtu.be/v9l|gKo[z]M

Correspondence: Guosheng Ren Chongqing Key Laboratory of Molecular Oncology and Epigenetics, The First Affiliated Hospital of Chongqing Medical University, No.I Youyi Road, Yuzhong District, Chongqing 400016, People's Republic of China

Tel +860 238 90। I477

Fax +860 2389012305

Email rengs726@126.com
Background: Recently, emerging evidence has indicated crucial roles for long noncoding RNAs (lncRNAs) in breast cancer (BC) development and progression. Our study aimed to investigate the clinical significance of LINC01089 in patients with BC and to determine its biological functions and underlying molecular mechanisms.

Materials and methods: Correlations between LINC01089 expression and the clinicopathological characteristics of BC patients were assessed using chi-square tests. The Kaplan-Meier method was used to produce survival curves. The clinical risk characteristics associated with the overall survival and recurrence-free survival of patients with $\mathrm{BC}$ were estimated using univariate and multivariate Cox regression analyses. Several methods were used to determine the expression profile, biological functions and underlying mechanisms of LINC01089 in BC, including cell proliferation assays, colony formation assays, flow cytometry, transwell assays, wound healing assays, quantitative real-time polymerase chain reaction and Western blotting.

Results: LINC01089 was downregulated in BC tissues and cell lines. Low LINC01089 expression was significantly correlated with age $(P=0.026)$, lymph node metastasis $(P=0.003)$, and poor prognosis of patients with BC. According to the multivariate Cox regression analysis results, LINC01089 was an independent prognostic indicator of overall survival $(P=0.032)$ and recurrence-free survival $(P=0.014)$. Functional studies revealed significant decreases in the proliferation, migration, and invasion of tumor cells overexpressing LINC01089, and EGF could reverse above effects of LINC01089 on BC cells. Additionally, increased LINC01089 expression promoted apoptosis and cell cycle arrest at G0/G1 phase, accompanied by decreased expression of the key cell cycle regulators CDK4 and CDK6. Loss-of-function assays confirmed partial results. Mechanistically, LINC01089 blocked the Wnt/ $\beta$-catenin pathway and the expression of downstream target genes by inhibiting $\beta$-catenin expression at the transcriptional level.

Conclusion: Based on our results, LINC01089 functions as a tumor suppressor and potentially represents a novel prognostic indicator and therapeutic target in BC.

Keywords: long noncoding RNA, breast cancer, prognostic indicator, tumor suppressor, the canonical Wnt signaling

\section{Introduction}

Breast cancer (BC) is the most common malignant cancer among women worldwide and a major cause of cancer-related deaths, accounting for an estimated $30 \%$ of new malignancy diagnoses in US females in $2019 .{ }^{1}$ Approximately $12.4 \%$ of 
women, or 1 in 8 , will be diagnosed with $\mathrm{BC}$ during their lifetime, ${ }^{2}$ of which approximately $5 \%$ will experience distant metastasis. ${ }^{3}$ Despite improvements in early detection and systemic therapies, the incidences of $\mathrm{BC}$ and metastasis-associated death are steadily increasing and remain unsatisfactory. ${ }^{1,3}$ Thus, studies aiming to elucidate the underlying molecular mechanisms of tumorigenesis and progression may hasten explorations of novel biomarkers and therapeutic measures for patients with $\mathrm{BC}$.

The canonical Wnt/ $\beta$-catenin signaling is a vital signaling pathway that markedly impacts biological processes, such as cell proliferation, migration, and stem cell differentiation. ${ }^{4-6}$ Without activating stimuli, $\beta$ catenin is degraded by multiprotein complexes composed of glycogen synthase kinase $3 \beta$ (GSK3 $\beta$ ), casein kinase-1 (CK1), adenomatous polyposis coli (APC), and Axin via the ubiquitin-proteasome pathway in the cytoplasm. ${ }^{7}$ Upon receipt of a Wnt signal, the activity of such multiprotein complexes is repressed. ${ }^{4} \beta$-Catenin initially accumulates and then binds to TCF/LEF (T-cell factor/lymphoid-enhancer factor), which regulates the transcription of downstream targets. ${ }^{4} \mathrm{Wnt} / \beta$-catenin signaling is abnormally activated in numerous tumors, including BC. ${ }^{8,9}$ Notably, aberrant accumulation of $\beta$ catenin has been found in up to $50 \%$ of patients with $\mathrm{BC}$, and this feature is strongly associated with a poor prognosis. ${ }^{9,10}$ Therefore, the identification of novel regulators and mechanisms of $\mathrm{Wnt} / \beta$-catenin signaling may provide new insights into therapeutic strategies for $\mathrm{BC}$.

Long noncoding RNAs (lncRNAs), which are more than 200 nucleotides long, are a group of RNAs that lack protein-coding capacity. ${ }^{11}$ Extensive studies have revealed versatile biological functions for lncRNAs in normal development, physiological processes and human disease. ${ }^{11-13}$ In particular, lncRNAs have been identified as crucial regulators of carcinogenesis and progression in many types of cancer, including BC. ${ }^{14}$ For instance, high HOTAIR expression levels in $\mathrm{BC}$ are a significant predictor of subsequent metastasis and death. ${ }^{15}$ The upregulation of the lncRNA GAS5 in BC cells inhibits cell proliferation and invasion. ${ }^{16}$ These results indicate the significance of investigations focusing on lncRNAs and BC.

The IncRNA LINC01089 (also known as LIMT, LncRNA Inhibiting Metastasis), which maps to chromosome 12, was first reported to be suppressed upon EGF (epidermal growth factor) stimulation of MCF-10A mammary cells, and LIMT expression was associated with clinical grade in $\mathrm{BC}$ patients. Moreover, $\mathrm{BC}$ cell migration and lung metastasis were inhibited by LIMT overexpression and promoted by LIMT knockdown. ${ }^{17}$ However, the precise functions and mechanisms of LINC01089 in BC have not been completely elucidated. In our study, we extensively explored the correlations between clinical features and LINC01089 expression in patients with BC. Based on the results of functional studies, LINC01089 functions as a tumor suppressor. And EGF could reverse the partial effects of LINC01089 on BC cells. Mechanistically, the ability of LINC01089 to regulate Wnt/ $\beta$-catenin signaling was first explored. Collectively, LINC01089 is an independent prognostic factor for BC patients, exerts an inhibitory effect on $\mathrm{BC}$ and serves as a promising mediator of the canonical $\mathrm{Wnt} / \beta$-catenin pathway.

\section{Materials and methods}

\section{Patient sample collection}

All primary breast carcinoma tissue samples and adjacent noncancerous tissue samples were collected from 63 patients with $\mathrm{BC}$ at the First Affiliated Hospital of Chongqing Medical University. All patients underwent surgery in the Endocrine Breast Surgery Department, and fresh samples were immediately snap-frozen in liquid nitrogen and stored at $-80{ }^{\circ} \mathrm{C}$. Tissue samples were evaluated and subjected to histological diagnosis by two expert pathologists. This study complied with the 1964 Declaration of Helsinki and was approved by the Ethics Committee of the First Affiliated Hospital of Chongqing Medical University (No. 2017-012). All patients provided informed consents prior to sample collection, and all patient consents were written informed consents.

Public data from the online database The Cancer Genome Atlas (TCGA), which contains information about gene expression in $\mathrm{BC}$ tissues and clinical features, were downloaded from the cBioPortal for Cancer Genomics (http://www.cbioportal.org/). ${ }^{18,19}$ Seven hundred forty-eight $\mathrm{BC}$ samples with complete clinical information (TCGA, Provisional) were included in our study.

\section{Cell culture and transfection}

Eight human BC cell lines, including MDA-MB-231, BT549, SUM-159, MDA-MB-468, SK-BR-3, MCF-7, YCCB1, and T47D cells, and one normal breast epithelial cell line, MCF-10A, were purchased from American Type Culture Collection (ATCC, Manassas, VA, USA). Eight tumor cell 
lines were cultured in RPMI-1640 medium (Gibco-BRL, Karlsruhe, Germany). EGF (Abcam, ab9697) was added at a final concentration of $10 \mathrm{ng} / \mathrm{ml} .{ }^{17} \mathrm{MCF}-10 \mathrm{~A}$ cells were cultured as previously described. ${ }^{20}$ All media were supplemented with $10 \%$ fetal bovine serum (Gibco-BRL). All cells were cultured in a $5 \% \mathrm{CO}_{2}$ atmosphere at $37{ }^{\circ} \mathrm{C}$.

The LINC01089 sequence (NR_002809.3) reported in the NCBI database was synthesized by GenScript (Nanjing, China) and then subcloned into the pEGFP-C1 vector (GenScript, China); the empty pEGFP-C1 vector was used as a control. Three LINC01089-specific small interfering RNAs (si-LINC01089-1, si-LINC01089-2 and si-LINC01089-3) and negative control small interfering RNAs (si-NC) were purchased from RiboBio (RiboBio Co, Ltd, Guangzhou, China). Forty-eight or seventy-two hours after transfection, LINC01089 expression was detected to determine the transfection efficiency in different groups. Lipofectamine 2000 (Invitrogen, Carlsbad, CA, USA) was used for cell transfection according to the guidelines supplied by the manufacturer. The sequences of LINC01089-specific siRNAs are shown in Table 1.

\section{RNA isolation and quantitative real-time polymerase chain reaction (RT-qPCR)}

Trizol reagents (Invitrogen, USA) were purchased to obtain total RNA samples from BC tissues and cells following the manufacturer's guidelines. Then, total RNA was reversely transcribed into cDNA using GoScript ${ }^{\mathrm{TM}}$ Reverse Transcription System kits (Promega, Madison, WI, USA). RT-qPCR was subsequently performed with SYBR Green PCR Master Mix (Invitrogen) on a 7500 Real-Time PCR System (Applied Biosystems, Foster

Table I List of LINC01089-specific siRNAs used in this study

\begin{tabular}{|l|l|}
\hline Name & Sequences \\
\hline si-LINC01089-I & CAAAAAGCTTGATCTTCTA \\
si-LINC01089-2 & AAAGCTTGATCTTCTAGAC \\
si-LINC01089-3 & TTGATCTTCTAGACTCCAT \\
\hline
\end{tabular}

City, CA). GAPDH served as a control in RT-qPCR assays. The primers used are shown in Table 2.

\section{Cell proliferation assays}

All cells were cultured in 96-well plates (transfected MDA-MB-231 and BT-549 cells at the density of $2 \times 10^{3}$ cells per well; transfected MDA-MB-468 and MCF-7 cells at the density of $5 \times 10^{3}$ cells per well). Then, cell viability was assessed at $24 \mathrm{hrs}, 48 \mathrm{hrs}$ and $72 \mathrm{hrs}$ by adding $10 \mu \mathrm{L}$ of Cell Counting Kit-8 (CCK-8) solution (C0037, Beyotime, Haimen, China) to each well and quantifying the absorbance at $450 \mathrm{~nm}$. After $2 \mathrm{hrs}$ incubation, a microplate reader from Thermo Fisher Scientific (formerly Fermentas, Schwerte, Germany) was used to monitor the results.

\section{Colony formation assays}

Transfected MDA-MB-231 cells (500 cells per well) and MDA-MB-468 cells (1000 cells per well) were cultured in 6-well plates in triplicate. After one week of incubation, the colonies in the plates were fixed with $4 \%$ paraformaldehyde for 30 mins and then stained with $0.1 \%$ crystal violet (C0121, Beyotime) at room temperature for 20 mins. Colonies containing $>50$ cells were counted.

\section{Flow cytometry analysis}

For cell cycle assays, cells were collected in centrifuge tubes after 3 mins of digestion with trypsin and resuspended in $100 \mu \mathrm{L}$ of PBS. Then, $400 \mu \mathrm{L}$ of $70 \%$ icecold ethanol was added dropwise to the cells in centrifuge tubes with shaking, and the cells were incubated overnight at $4{ }^{\circ} \mathrm{C}$. Then, the cell cycle distribution of tumor cells was assayed with a FACSCalibur flow cytometer (BD Biosciences, Franklin Lakes, US) after staining with propidium iodide (PI). In the apoptosis analysis, the cells were harvested in centrifuge tubes. After two washes with PBS, the cells were stained with both annexin V-FITC and PI (both from Sigma-Aldrich) in the dark for 30 mins and immediately analyzed by flow cytometry.

Table 2 List of primers used in this study

\begin{tabular}{|l|l|l|l|}
\hline Name & Forward primer $\left(\mathbf{5}^{\prime} \mathbf{- 3} \mathbf{\prime}\right)$ & Reverse primer $\left(\mathbf{5}^{\prime} \mathbf{-} \mathbf{3}^{\prime} \mathbf{)}\right.$ & Product size \\
\hline LINC0I089 & GCAGTAAACAGTCCTCAGCGAAG & CGGTGCCATGGAGTCTAGAAGAT & $128 \mathrm{bP}$ \\
CTNNBI & ATTGTCCACGCTGGATTTTC & TCGAGGACGGTCGGACT & $97 \mathrm{bP}$ \\
CCNDI & CTAGCAAGCTGCCGAACC & TCCGAGCACAGGATGACC & $90 \mathrm{bP}$ \\
MYC & GGAGGCTATTCTGCCCATTT & GTCGAGGTCATAGTTCCTGTTGG & $177 \mathrm{bP}$ \\
GAPDH & CCAGCAAGAGCACAAGAGGAA & GGTCTACATGGCAACTCAAGG & $114 \mathrm{bP}$ \\
\hline
\end{tabular}




\section{Transwell assays}

The transwell chamber inserts (Corning Inc., Corning, NY) used in the present study have $8-\mu \mathrm{m}$ pores. For transwell migration assays, transfected MDA-MB-231 and BT-549 cells $\left(1 \times 10^{5}\right.$ cells $\left./ \mathrm{mL}\right)$ or MCF-7 and MDA-MB-468 cells $\left(2 \times 10^{5}\right.$ cells $\left./ \mathrm{mL}\right)$ were separately resuspended in $200 \mu \mathrm{L}$ of serum-free RPMI-1640 medium and seeded in the upper chambers. After a 12- to $48 \mathrm{hr}$ incubation, tumor cells that migrated through the membrane pores were fixed with $4 \%$ paraformaldehyde for 30 mins and stained with $0.1 \%$ crystal violet. Prior to the transwell invasion assay, Matrigel $(30 \mu \mathrm{g} /$ well; BD Biosciences, San Jose, CA) was precoated on the membranes of the upper chambers. The subsequent procedures were the same as those for the cell migration assay. The number of migratory or invasive cells was counted in five random fields under a microscope.

\section{Wound healing assays}

Cells were plated in 6-well plates and allowed to reach 95-100\% confluence for the wound healing assays. A pipette tip was used to gently scratch the cell monolayer. After two washes with PBS, the cells were cultured with serum-free RPMI-1640 medium. Images of migrating cells were captured at different times using a microscope (Leica DMI4000B, Milton Keynes, Bucks, UK).
A

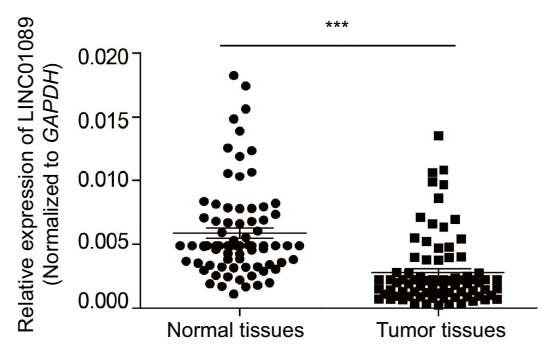

C

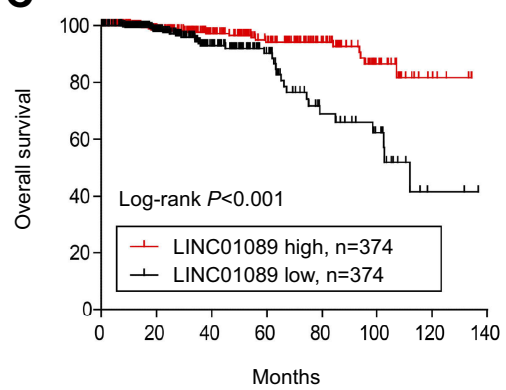

B

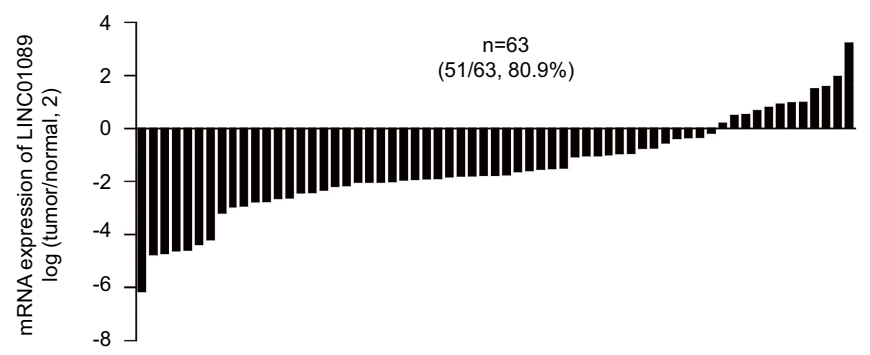

D

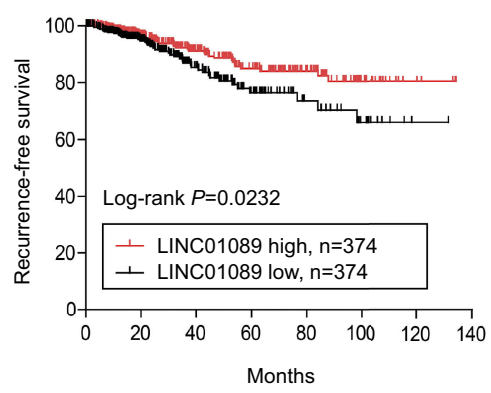

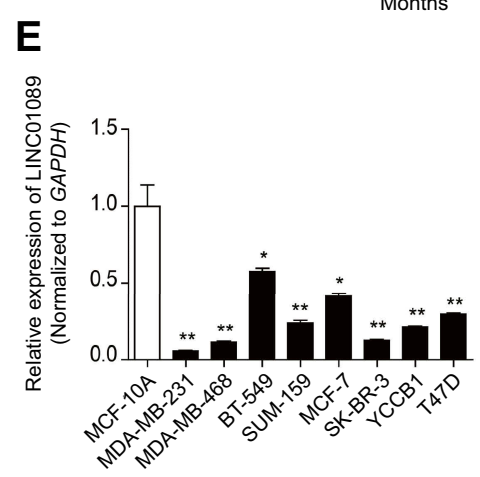

$\mathbf{F}$

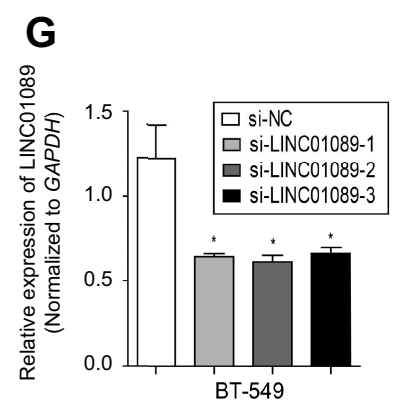

Figure I Decreased LINC0I089 expression predicts a poor prognosis for patients with BC.

Notes: (A) LINC01089 expression in 63 paired BC samples and adjacent noncancerous samples was detected using RT-qPCR. (B) Comparison of LINC0I089 mRNA levels in BC tissues and adjacent noncancerous tissues. The OS (C) and RFS (D) of patients with BC were analyzed using the Kaplan-Meier method. All 748 patients with BC were divided based on the median LINC0I089 expression value into the following groups: LINC0I089 high group ( $n=374)$ and LINC0I089 low group ( $n=374)$. (E) The LINC0I089 expression profile in human BC cells was assayed using RT-qPCR. (F) The transfection efficiency in stable LINC01089-overexpressing cells (MDA-MB-23I and MDA-MB-468) was evaluated using RT-qPCR. (G) Three LINC01089-specific siRNAs were transfected into BT-549 cells. Mean \pm SD, $n=3$, $* P<0.05$, $* * P<0.01$, and $* * * P<0.001$.

Abbreviations: BC, breast cancer; RT-qPCR, quantitative real-time polymerase chain reaction; OS, overall survival; RFS, recurrence-free survival. 
Table 3 Correlation between LINC0I089 expression levels and clinicopathological features of 748 BC patients in TCGA cohort

\begin{tabular}{|c|c|c|c|c|}
\hline \multirow[t]{2}{*}{ Characteristic } & \multirow[t]{2}{*}{$\begin{array}{l}\text { Number } \\
\text { of cases }\end{array}$} & \multicolumn{2}{|c|}{$\begin{array}{l}\text { LINC0I089 } \\
\text { expression }\end{array}$} & \multirow[t]{2}{*}{$P$-value } \\
\hline & & $\begin{array}{l}\text { Low } \\
(n=374)\end{array}$ & $\begin{array}{l}\text { High } \\
(n=374)\end{array}$ & \\
\hline $\begin{array}{l}\text { Age } \\
<60 \\
\geq 60\end{array}$ & $\begin{array}{l}436 \\
312\end{array}$ & $\begin{array}{l}203 \\
17 \mid\end{array}$ & $\begin{array}{l}233 \\
141\end{array}$ & 0.026 \\
\hline $\begin{array}{l}\text { Tumor size } \\
\leq 2 \mathrm{~cm} \\
>2 \mathrm{~cm}\end{array}$ & $\begin{array}{l}191 \\
557\end{array}$ & $\begin{array}{l}92 \\
282\end{array}$ & $\begin{array}{l}99 \\
275\end{array}$ & 0.663 \\
\hline $\begin{array}{l}\text { Lymph node } \\
\text { metastasis } \\
\text { No } \\
\text { Yes }\end{array}$ & $\begin{array}{l}380 \\
368\end{array}$ & $\begin{array}{l}170 \\
204\end{array}$ & $\begin{array}{l}210 \\
164\end{array}$ & 0.003 \\
\hline $\begin{array}{l}\text { TNM stage } \\
\text { I-II } \\
\text { III-IV }\end{array}$ & $\begin{array}{l}581 \\
167\end{array}$ & $\begin{array}{l}297 \\
77\end{array}$ & $\begin{array}{l}284 \\
90\end{array}$ & 0.254 \\
\hline $\begin{array}{l}\text { ER } \\
\text { Negative } \\
\text { Positive }\end{array}$ & $\begin{array}{l}179 \\
569\end{array}$ & $\begin{array}{l}84 \\
290\end{array}$ & $\begin{array}{l}95 \\
279\end{array}$ & 0.346 \\
\hline $\begin{array}{l}\text { PR } \\
\text { Negative } \\
\text { Positive }\end{array}$ & $\begin{array}{l}247 \\
501\end{array}$ & $\begin{array}{l}121 \\
253\end{array}$ & $\begin{array}{l}126 \\
248\end{array}$ & 0.697 \\
\hline $\begin{array}{l}\text { HER2 } \\
\text { Negative } \\
\text { Positive }\end{array}$ & $\begin{array}{l}619 \\
129\end{array}$ & $\begin{array}{l}313 \\
61\end{array}$ & $\begin{array}{l}306 \\
68\end{array}$ & 0.498 \\
\hline
\end{tabular}

Abbreviations: BC, breast cancer; TCGA, The Cancer Genome Atlas; ER, estrogen receptor; PR, progesterone receptor; HER2, human epidermal growth factor receptor-2.

\section{Western blotting}

Western blotting was performed as previously described. ${ }^{21}$ The following antibodies were used in the present study: nonphosphorylated (active) $\beta$-catenin ${ }^{\text {Ser45 }}$ (Cell Signaling
Technology, \#19,807), nonphosphorylated (active) $\beta$ -

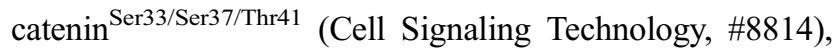
total $\beta$-catenin (Cell Signaling Technology, \#2677), cyclin D1 (Cell Signaling Technology, \#2978), c-Myc (Cell Signaling Technology, \#13,987), CDK4 (Cell Signaling Technology, \#2906), CDK6 (Cell Signaling Technology, \#3136), and $\beta$-actin (Santa Cruz Biotechnology, sc-47,778).

\section{Statistical analysis}

GraphPad Prism 5.0 software (San Diego, CA, USA) and IBM SPSS 23.0 software (SPSS Inc., Chicago, IL, USA) were used for statistical analyses. A two-tailed Student's $t$-test was used to compare the significance of differences between the experimental and control groups. Correlations between clinicopathological risk factors and LINC01089 expression in $\mathrm{BC}$ patients were analyzed by chi-square tests. The Kaplan-Meier method with the log-rank test was used to produce survival curves. Univariate and multivariate Cox regression analyses were performed to analyze clinical risk characteristics associated with the overall survival (OS) and recurrence-free survival (RFS) of patients with BC. $P<0.05$ was considered statistically significant.

\section{Results}

\section{Decreased LINC0I089 expression predicts a poor prognosis for patients with BC}

Sixty-three paired breast tumor tissues and adjacent noncancerous tissues were used to detect the expression profile of LINC01089 by RT-qPCR (Figure 1A). LINC01089 expression was significantly downregulated in $80.9 \%(51 / 63)$ of breast tumor tissues compared with adjacent noncancerous tissues (Figure 1B). We further

Table 4 Univariate analyses of clinical risk factors in BC patients

\begin{tabular}{|c|c|c|c|c|c|c|}
\hline \multirow[t]{2}{*}{ Variants } & \multicolumn{3}{|c|}{ Overall survival } & \multicolumn{3}{|c|}{ Recurrence-free survival } \\
\hline & HR & $95 \% \mathrm{Cl}$ & $P$-value & HR & $95 \% \mathrm{Cl}$ & $P$-value \\
\hline Age $(<60$ vs $\geq 60)$ & 1.332 & $0.674-2.632$ & 0.409 & 1.062 & $0.647-1.744$ & $0.8 \mathrm{II}$ \\
\hline Tumor size $(\leq 2 \mathrm{~cm}$ vs $>2 \mathrm{~cm})$ & 1.762 & $0.768-4.045$ & 0.181 & 2.011 & $1.098-3.686$ & 0.024 \\
\hline Lymph node metastasis (no vs yes) & 2.410 & I. $180-4.923$ & 0.016 & 1.852 & $1.135-3.022$ & 0.014 \\
\hline TNM stage (I/II vs III/IV) & 4.610 & $2.367-8.980$ & $<0.001$ & 3.066 & $1.895-4.960$ & $<0.001$ \\
\hline ER (negative vs positive) & 3.217 & $1.656-6.249$ & 0.001 & 1.962 & $0.311-0.835$ & 0.007 \\
\hline PR (negative vs positive) & 2.489 & I.279-4.843 & 0.007 & 1.473 & $0.909-1.2389$ & 0.116 \\
\hline HER2 (negative vs positive) & $\mathrm{I} .797$ & $0.549-5.884$ & 0.333 & 1.367 & $0.652-2.857$ & 0.409 \\
\hline LINC01089 (low vs high) & 1.977 & $1.009-3.874$ & 0.047 & 1.679 & $1.039-2.713$ & 0.034 \\
\hline
\end{tabular}

Abbreviations: HR, hazard ratio; $\mathrm{Cl}$, confidence interval; ER, estrogen receptor; PR, progesterone receptor; HER2, human epidermal growth factor receptor-2. 
Table 5 Multivariate Cox regression analyses of clinical risk factors in BC patients

\begin{tabular}{|l|l|l|l|l|l|l|}
\hline \multirow{2}{*}{ Variants } & \multicolumn{2}{l|}{ Overall survival } & \multicolumn{2}{l|}{ Recurrence-free survival } \\
\cline { 2 - 7 } & $\mathbf{H R}$ & $\mathbf{9 5 \%} \mathbf{~ C l}$ & $\boldsymbol{P}$-value & HR & $\mathbf{9 5 \%} \mathbf{C l}$ & $\mathbf{P}$-value \\
\hline Lymph node metastasis (no vs yes) & 1.267 & $0.494-3.249$ & 0.622 & 1.185 & $0.639-2.198$ & 0.591 \\
TNM stage (I/II vs III/IV) & 6.199 & $2.530-15.194$ & $<0.001$ & 3.129 & $1.693-5.785$ & $<0.001$ \\
ER (negative vs positive) & 3.780 & $1.361-10.503$ & 0.001 & 2.415 & $1.453-4.015$ & 0.001 \\
LINC0I089 (low vs high) & 2.102 & $1.065-4.149$ & 0.032 & 1.841 & $1.132-2.994$ & 0.014 \\
\hline
\end{tabular}

Abbreviations: $\mathrm{HR}$, hazard ratio; $\mathrm{Cl}$, confidence interval; $\mathrm{ER}$, estrogen receptor.

identified the clinicopathological factors associated with LINC01089 expression in BC and its prognostic significance. LINC01089 expression levels were significantly correlated with age $(P=0.026)$ and lymph node metastasis $(P=0.003)$ (Table 3). Patients with $\mathrm{BC}$ presenting decreased LINC01089 expression displayed a shorter OS $(P<0.001)$ (Figure 1C) and RFS $(P=0.0232)$ (Figure 1D). Univariate analyses of clinical characteristics showed that lymph node metastasis, TNM stage, ER (estrogen receptor), and LINC01089 expression were four risk factors which significantly correlated with both shorter OS and RFS in BC patients (Table 4). Additionally, LINC01089 served as an independent prognostic indicator for $\mathrm{OS} \quad(\mathrm{HR}=2.102, \quad 95 \%$ $\mathrm{CI}=1.065-4.149, P=0.032)$ and RFS $(\mathrm{HR}=1.841,95 \%$ $\mathrm{CI}=1.132-2.994, P=0.014)$ of $\mathrm{BC}$ patients according to the multivariate Cox regression analysis (Table 5). Thus, low LINC01089 expression was strongly correlated with poor clinical prognosis in $\mathrm{BC}$ patients.

\section{LINC0I089 is downregulated in breast cancer cells}

Then, we determined the expression pattern of LINC01089 in eight $\mathrm{BC}$ cell lines, including MDA-MB-231, MDAMB-468, BT-549, SUM-159, SK-BR-3, MCF-7, YCCB1, and T47D cells, compared with one normal breast epithelial cell line, MCF-10A cells. RT-qPCR assay showed that LINC01089 expression was markedly downregulated in all tested breast tumor cells compared with MCF-10A (Figure 1E).

To investigate the biological functions of LINC01089 in BC, we performed a series of functional studies in BC cells. According to above results, LINC01089 expression was relatively lower in MDAMB-231 and MDA-MB-468 cells but higher in BT-549 and MCF-7 cells. Thus, we overexpressed LINC01089 in MDA-MB-231 and MDA-MB-468 cells, while the
BT-549 and MCF-7 cell lines were selected for loss-offunction studies and were transfected with LINC01089specific siRNA. Transfection efficiencies were confirmed using RT-qPCR, and si-LINC01089-2 was chosen for subsequent assays due to its significant knockdown of LINC01089 (Figure 1F and G).

\section{Ectopic LINC0I089 expression suppresses $\mathrm{BC}$ cell proliferation and induces cell cycle to arrest at G0/GI phase} Cell viability of transfected BC cells was assessed respectively to identify the effects of LINC01089 on cell proliferation. LINC01089 overexpression significantly decreased tumor cell viability compared with the vector control (Figure 2A). In contrast, the downregulation of endogenous LINC01089 expression in BT-549 and MCF-7 cells by transfecting si-LINC 01089-2 increased cell viability (Figure 2B). Moreover, colony formation assays revealed a lower relative colony formation rate for LINC01089transfected cells than controls (Figure 2C).

Moreover, we investigated the proportion of tumor cells in each cell cycle phase using flow cytometry to identify whether LINC01089 impedes BC cell proliferation via cell cycle progression. Cell cycle assays showed that the distribution of LINC01089-overexpressing cells was noticeably enhanced in $\mathrm{G} 0 / \mathrm{G} 1(63.36 \%$ vs $54.73 \%$ in the control group of MDA-MB -231 cells; $69.18 \%$ vs $61.90 \%$ in the control group of MDAMB-468 cells) phase but was reduced in S and G2/M phases (Figure 2D and E), accompanied by the decreased expression of key regulators of $\mathrm{G} 0 / \mathrm{G} 1$ phase, CDK4 and CDK6 (Figure 2H). The distribution of BT-549 and MCF-7 cells after LINC01089 knockdown was decreased in G0/G1 phase $(64.69 \%$ vs $68.04 \%$ in the control group of BT-549 cells; $67.76 \%$ vs $79.59 \%$ in the control group of MCF-7 cells) but remarkably increased in S phase (10.42\% vs $23.04 \%$ in MCF$7 ; 19.38 \%$ vs $24.19 \%$ in BT-549), which indicated that 
A

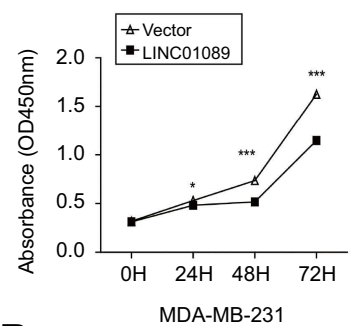

B

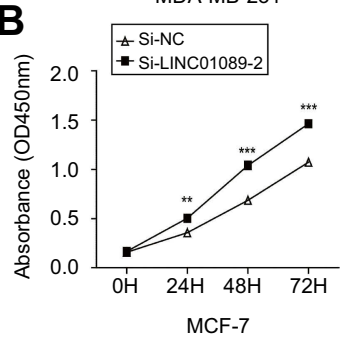

D
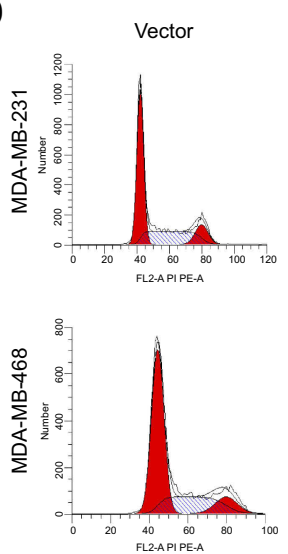

E
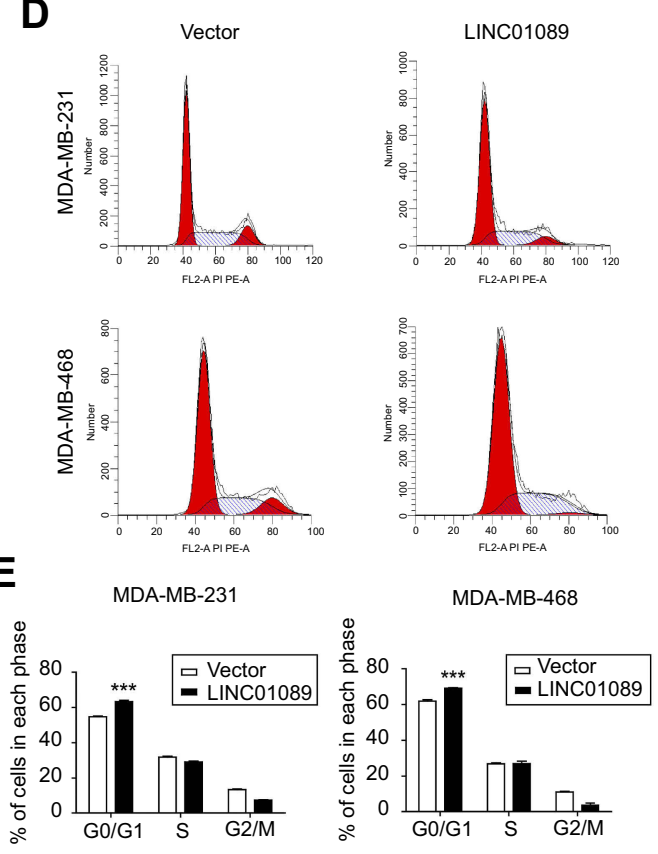

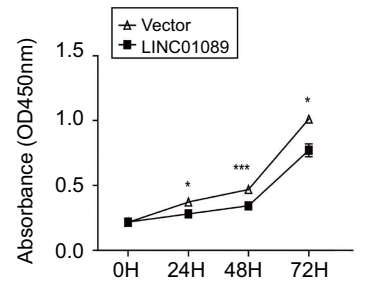

MDA-MB-468

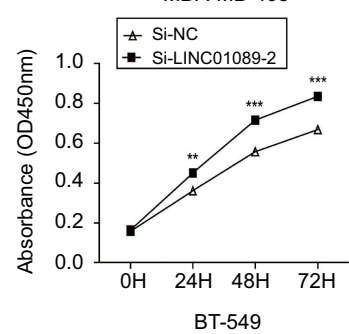

F
C
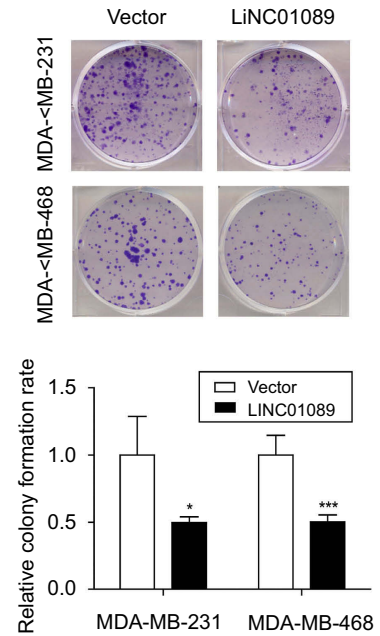
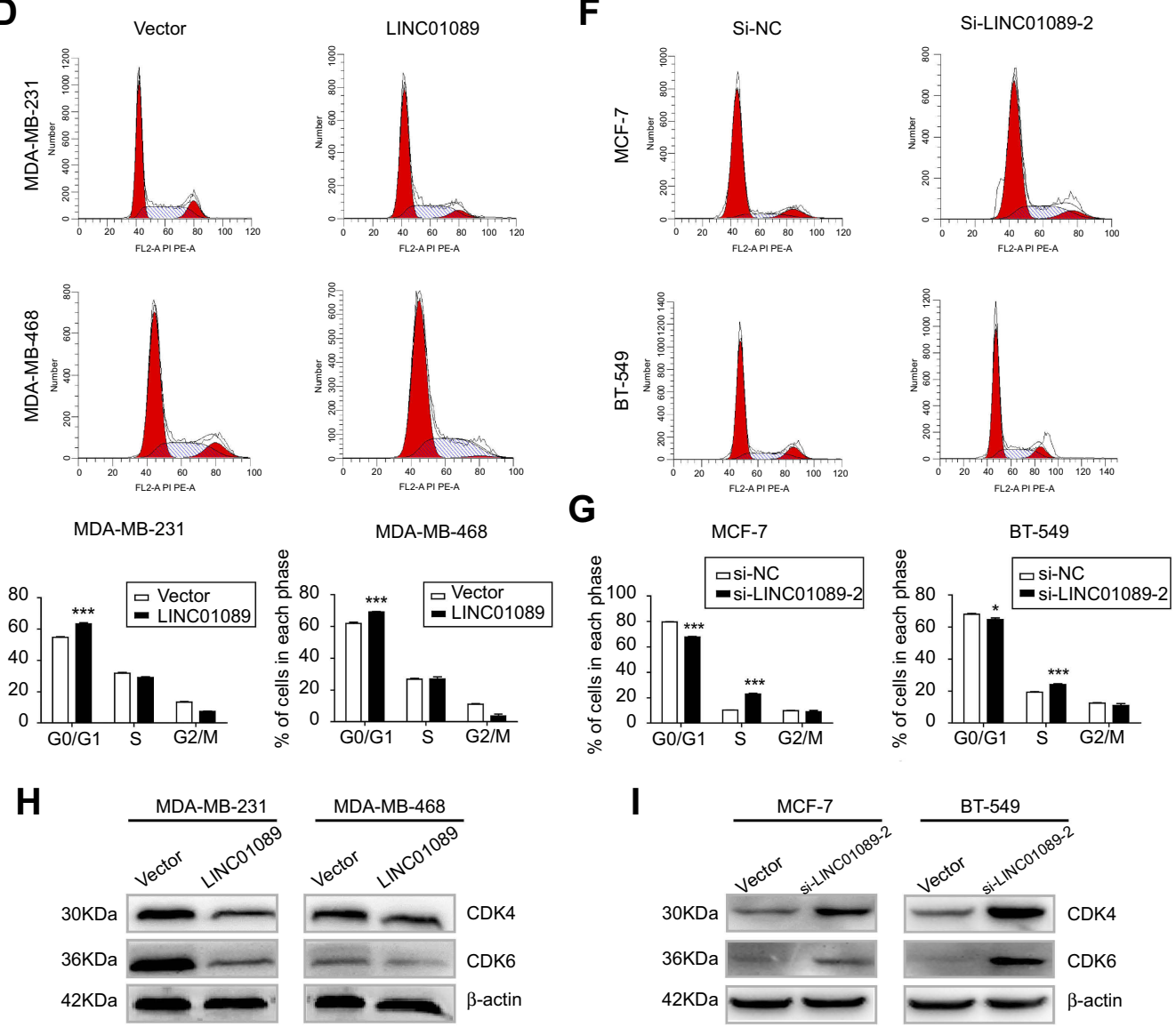

Figure 2 The effects of LINCOI089 on BC cell proliferation and cell cycle.

Notes: (A and B) The effects of LINC0I089 on BC cell proliferation were measured by CCK-8 assays. (C) Representative images of the colonies formed by LINC0I089transfected cells compared with controls. (D and E) The distribution of LINC0 I089-overexpressing cells in each cell cycle phase. (F and $\mathbf{G})$ Cell cycle distribution of MCF-7 and BT-549 cells after LINC0I089 knockdown. (H) Expression levels of cell cycle-related proteins in LINC0I089-overexpressing cells. (I) Expression levels of cell cyclerelated proteins in LINC0I089 knockdown cells. Mean \pm SD, $n=3, * P<0.05, * * P<0.01$, and $* * * P<0.001$.

Abbreviations: BC, breast cancer; CCK-8, Cell Counting Kit-8.

LINC01089 knockdown promoted the transition from G1 to $\mathrm{S}$ phase (Figure $2 \mathrm{~F}$ and $\mathrm{G}$ ), as confirmed by the increased expression of CDK4 and CDK6 (Figure 2I).

\section{LINC0I 089 promotes BC cell apoptosis}

Then, we investigated the apoptosis rate using flow cytometry to determine the effect of LINC01089 on apoptosis. As shown 
A
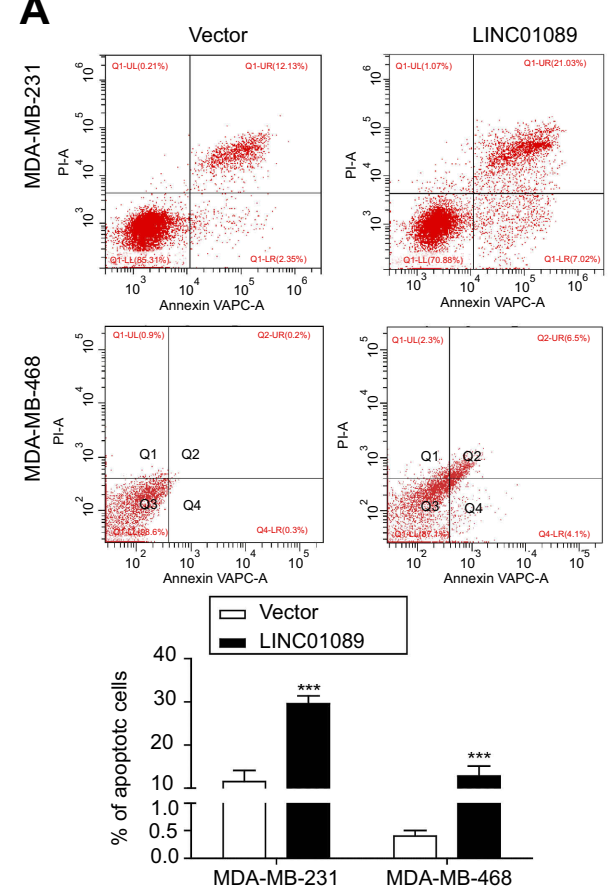

B
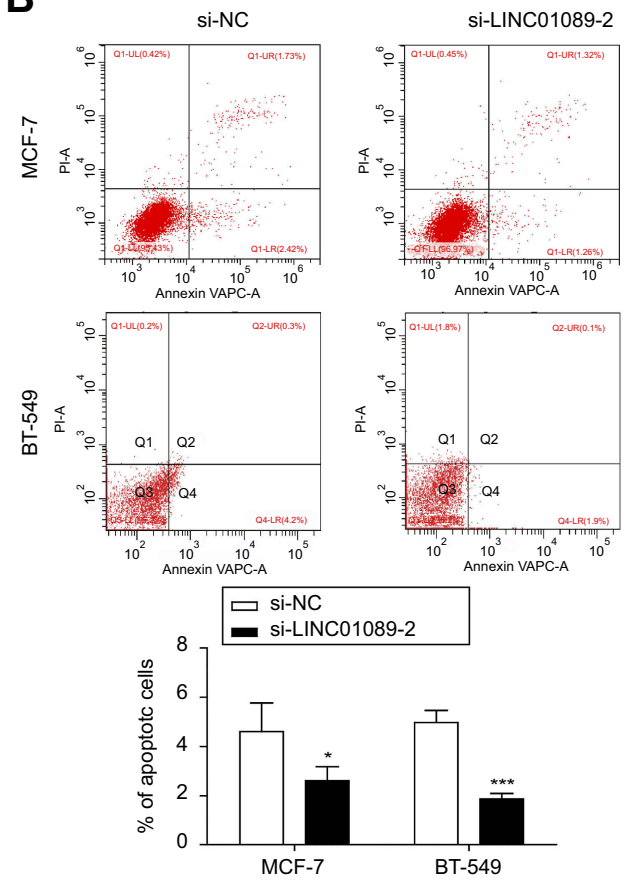

Figure 3 LINC01089 promotes BC cell apoptosis.

Notes: (A) The percentage of apoptotic LINC01089-overexpressing cells was evaluated. (B) The proportion of apoptotic MCF-7 and BT-549 cells was measured after LINC0I089 knockdown. Mean \pm SD, $n=3, * P<0.05$ and $* * * P<0.001$.

Abbreviation: $\mathrm{BC}$, breast cancer.

in Figure 3A, the apoptosis assays showed a marked increase in the total proportion of apoptotic LINC01089overexpressing MDA-MD-231 cells $(29.56 \%$ vs $11.53 \%$ in the control group) and MDA-MD-468 cells (12.8\% vs $0.40 \%$ in the control group). Conversely, the proportions of apoptotic cells decreased in BT-549 (1.87\% vs $4.97 \%$ in the control group) and MCF-7 cells $(2.61 \%$ vs $4.61 \%$ in the control group) after LINC01089 knockdown (Figure 3B).

\section{LINC0 I089 attenuates BC cell migration and invasion}

We suspected that LINC01089 might affect cell migration in addition to its inhibitory effect on cell growth, and thus, wound healing assays were conducted. LINC01089 overexpression impeded MDA-MB-231 cell mobility compared with the control, while LINC01089 knockdown in MCF-7 cells exerted the opposite effect (Figure 4A). Additionally, migratory and invasive cell numbers of transfected cells were further assessed by transwell assays. The numbers of migration (Figure 4B) and invasion (Figure 4C) cells were significantly decreased in BC cells after LINC01089 overexpression. Conversely, the numbers of migratory
(Figure 4D) and invasive (Figure 4E) BT-549 and MCF-7 cells were markedly increased by LINC01089 silencing.

\section{EGF reverses the effects of LINCOI089 on BC cells}

LINC01089 was downregulated in MCF-10A mammary cells upon EGF stimulation, and the numbers of migrating cells were significantly increased in response to EGF after LIMT knockdown in normal breast epithelial MCF-10A cells. ${ }^{17}$ Therefore, several functional studies were performed to investigate the effects of EGF on BC cells following ectopic LINC01089 expression. CCK-8 assays showed that LINC01089mediated inhibition of MDA-MB-231 cell growth was restored by EGF treatment (Figure 5A). Meanwhile, the apoptosis assay results revealed that LINC01089elicited BC cell apoptosis was apparently impeded by EGF stimulation (Figure 5B). Moreover, the transwell assays showed that decreased cells of migration and invasion in MDA-MB-231 after exogenous overexpression of LINC01089 were reversed by EGF treatment (Figure 5C). 
A
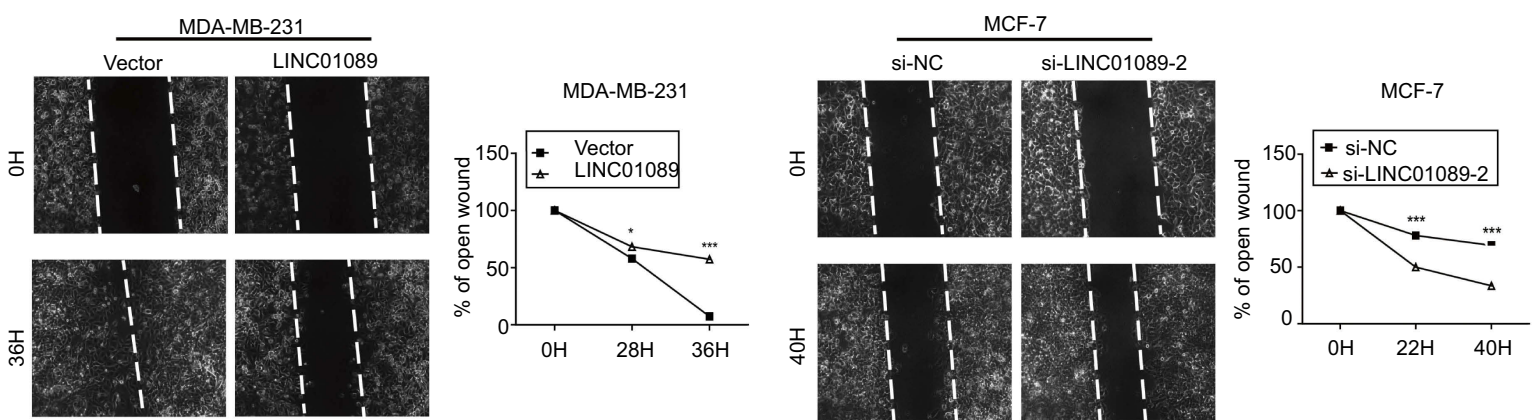

B
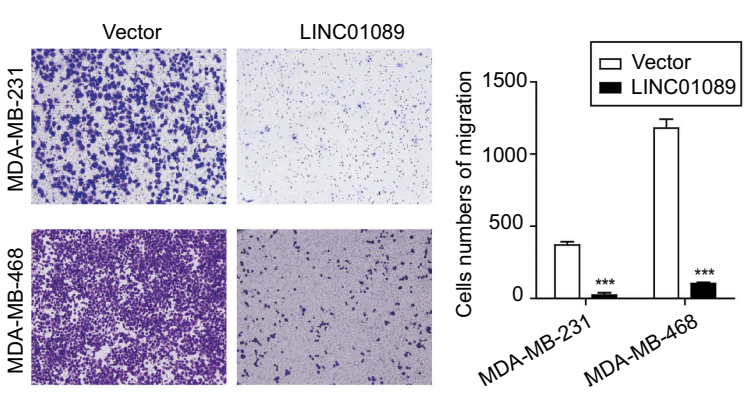

C

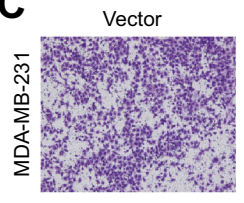

LINC01089
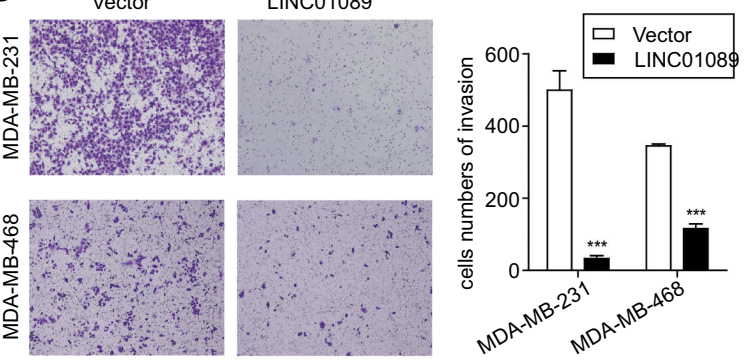

D
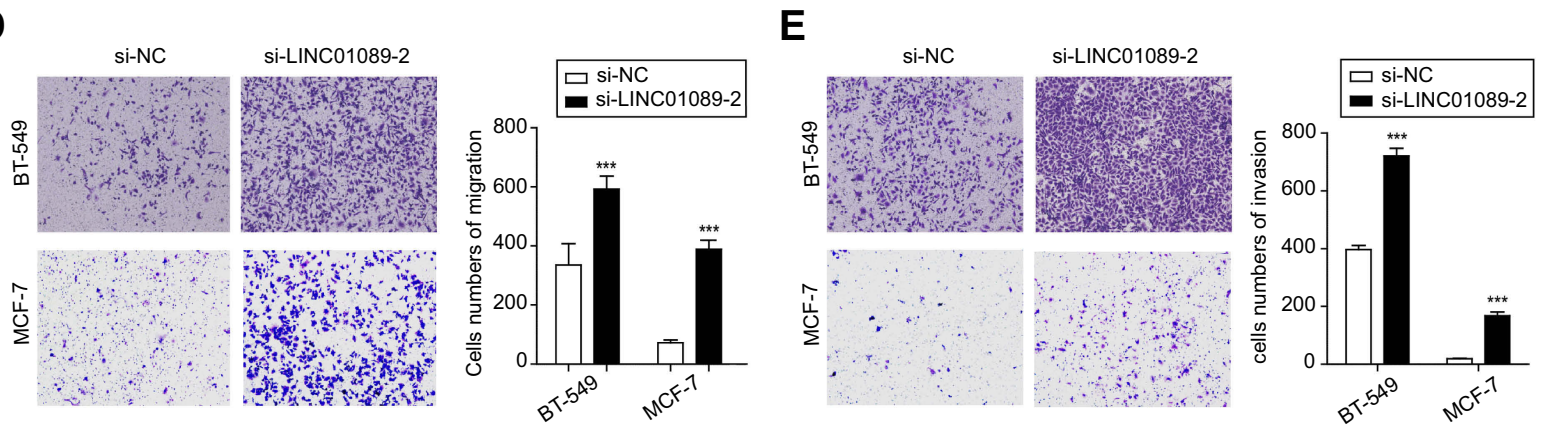

Figure 4 LINC0I089 attenuates BC cell migration and invasion.

Notes: (A) The percentage of open wounds was calculated to determine the migratory ability of transfected BC cells. The representative wound healing ratio is shown. The migratory (B) and invasive (C) potential of BC cells overexpressing LINC0I089 was evaluated by transwell assays. The numbers of cell migration (D) and invasion (E) in BT549 and MCF-7 cells after LINC0I089 knockdown. The average numbers of migratory and invasive cells per field are shown in histograms after calculation from five representative fields. Mean $\pm S D, n=3, * p<0.05$ and $* * * p<0.001$.

Abbreviation: $\mathrm{BC}$, breast cancer

\section{LINC0I089 inhibits wnt/ $\beta$-catenin pathway through downregulating $\beta$-catenin expression}

Dysregulation of canonical Wnt signaling mediates the development and progression of $\mathrm{BC}^{22,23} \beta$-Catenin, a pivotal component in $\mathrm{Wnt} / \beta$-catenin signaling, undergoes aberrant nuclear translocation in over $50 \%$ of $\mathrm{BC}$ cases, which is strongly correlated with a worse prognosis. ${ }^{9,10}$ To identify the potential mechanism underlying the inhibitory roles of LINC01089 in BC cells, we asked whether LINC01089 regulates Wnt/ $\beta$ catenin signaling. Western blots showed decreased levels of total $\beta$-catenin, active $\beta$-catenin ${ }^{\text {Ser45 }}$, active $\beta$-catenin ${ }^{\text {Ser33/Ser37/Thr41 }}$ and several downstream target proteins, including cyclin D1 and c-Myc, in cells overexpressing LINC01089 (Figure 6A). Interestingly, RTqPCR assays revealed a significant downregulation of the mRNA level of $\beta$-catenin (CTNNB1) in BC cells overexpressing LINC01089, indicating that the LINC01089-mediated inhibitory effect on $\beta$-catenin is largely mediated by transcriptional regulation (Figure 6B). Meanwhile, the expression of the downstream target genes CCND1 and MYC was decreased, as assessed using RT-qPCR (Figure 6C and D). Based on these findings, LINC01089 overexpression blocked Wnt/ $\beta$-catenin pathway by impeding $\beta$-catenin transcription. 


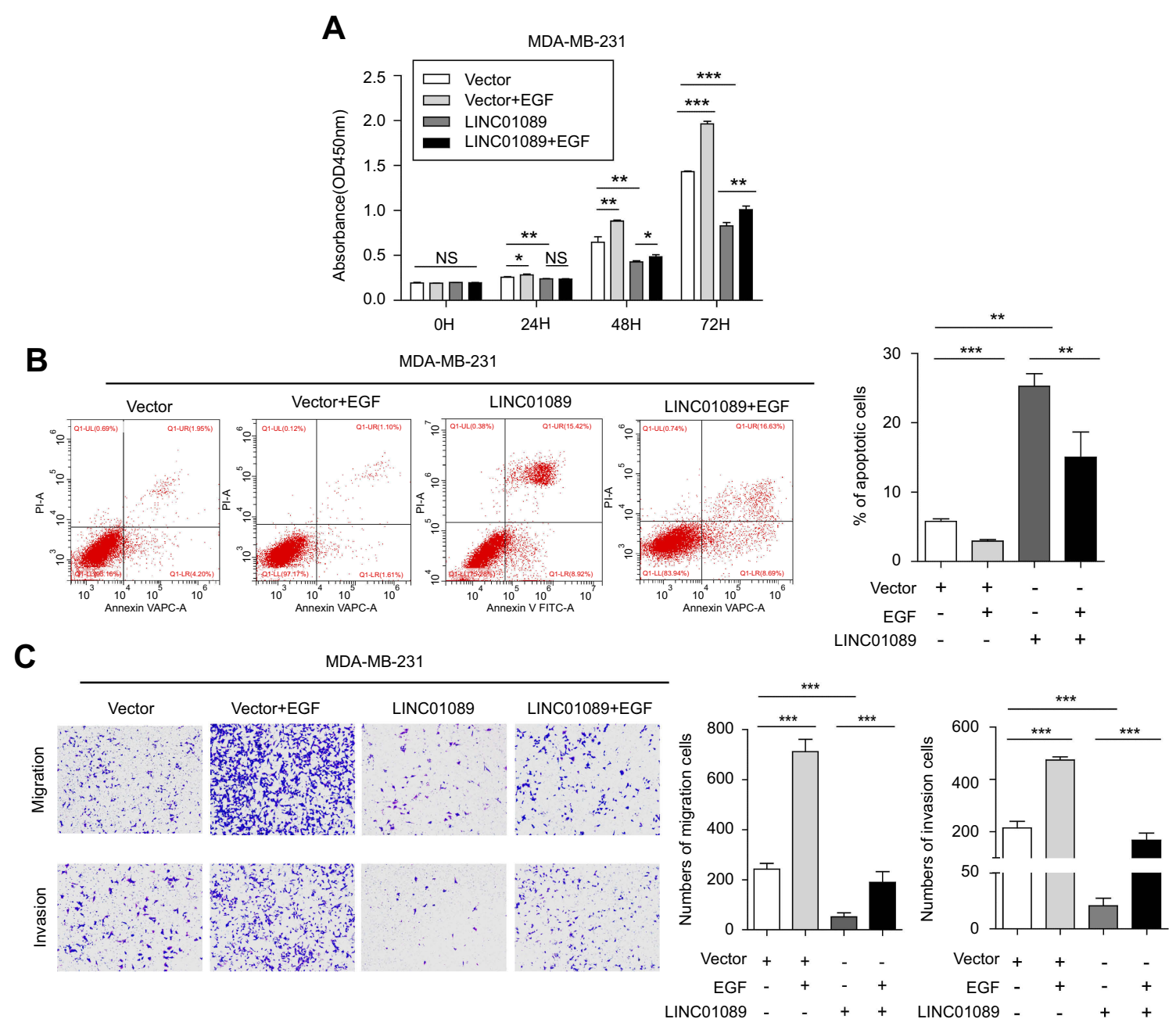

Figure 5 EGF reverses the effects of LINC0I089 on BC cells.

Notes: (A) The effects of EGF on LINC0 1089-overexpressing BC cell proliferation were measured by CCK-8 assays. (B) The increased percentage of apoptotic MDA-MB $-23 \mathrm{I}$ cells was restored by EGF treatment after LINC0I089 overexpression. (C) The migratory and invasive potential of LINC0I089-overexpressing BC cells stimulated with EGF was evaluated by transwell assays. Mean $\pm S D, n=3, * P<0.05, * * P<0.01$, and $* * * P<0.001$.

Abbreviations: EGF, epidermal growth factor; BC, breast cancer; CCK-8, Cell Counting Kit-8.

\section{Discussion}

Recent evidence suggests that lncRNAs are closely related to $\mathrm{BC}$ occurrence and development. ${ }^{24-26}$ The IncRNA LINC01089/LIMT is located on chromosome 12; LINC01089 downregulation was reported in BC, LIMT was shown to exert inhibitory effects on cell migration and lung metastasis. In addition, Sas-Chen et al explored the role of LINC01089 in BC patients with clinical datasets $\left(>2,000 \mathrm{BC}\right.$ patients). ${ }^{17}$ In our study, we confirmed some of the results above with different datasets, including $63 \mathrm{BC}$ patients from our hospital and $748 \mathrm{BC}$ patients from the TCGA database. Our results showed that LINC01089 expression was markedly downregulated in $80.9 \%(51 / 63)$ of human breast tumor tissue samples and in eight human BC cell lines. LINC01089 overexpression suppressed BC cell proliferation, migration and invasion, promoted cell apoptosis and cell cycle arrest at G0/G1 phase, while LINC01089 knockdown exhibited the opposite results. LINC01089 expression levels were strongly correlated with age and lymph node metastasis in patients with BC. Our survival analysis revealed a worse OS and RFS in patients with BC presenting low LINC01089 expression than in patients presenting high LINC01089 expression. Furthermore, LINC01089 was an independent prognostic indicator of OS and RFS for BC patients, according to the multivariate analysis. Based on these results, LINC01089 could be a novel predictor of prognosis for BC patients.

All tumors undergo unscheduled proliferation due to disruptions of the normal cell cycle. ${ }^{27}$ The kinases CDK4 and 
A

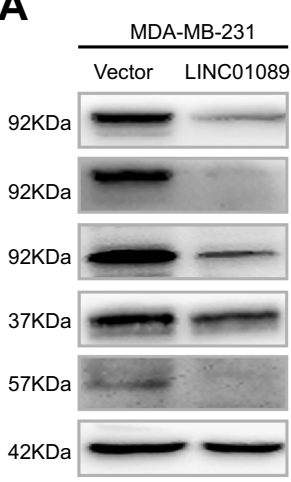

C
B

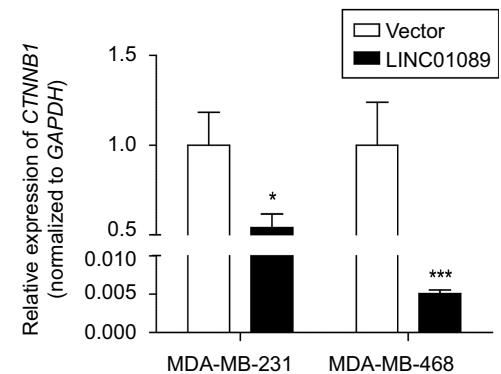

D
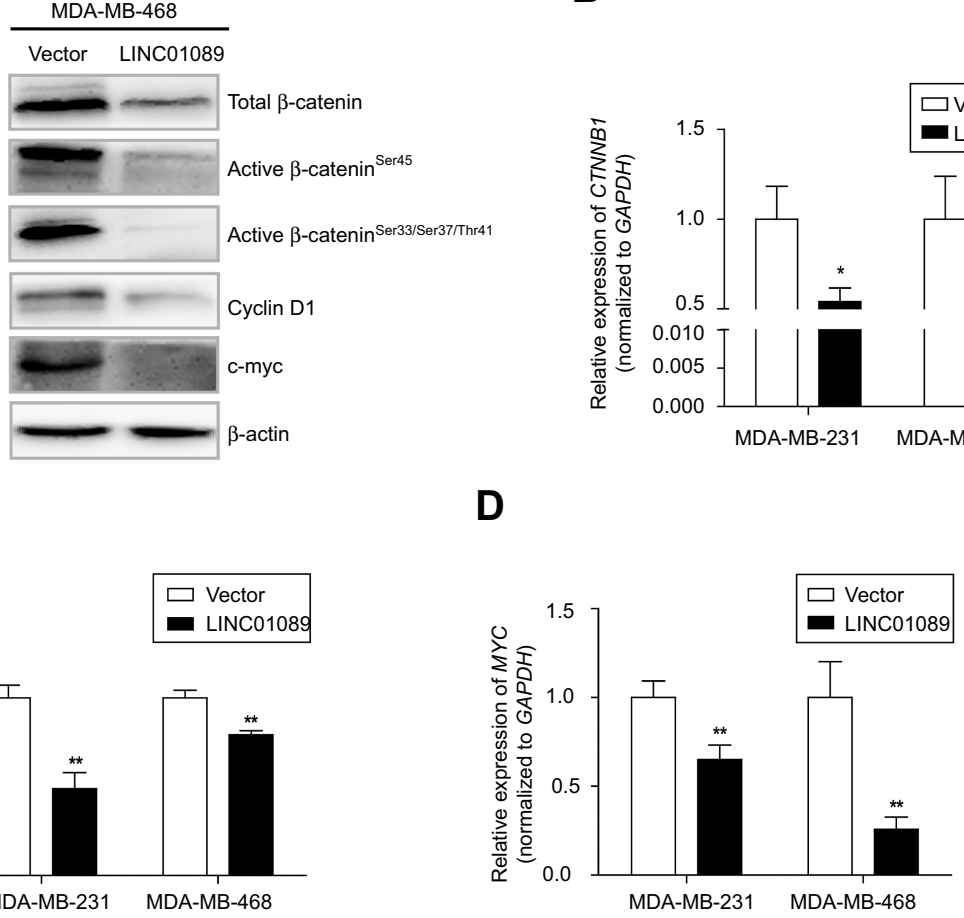

Figure 6 LINC0I089 inhibits Wnt/ $\beta$-catenin signaling.

Notes: (A) The levels of total $\beta$-catenin, active $\beta$-catenin, and several downstream target proteins were decreased upon ectopic expression of LINC0I089. RT-qPCR revealed significantly reduced expression of CTNNBI (B), CCNDI (C) and MYC (D) mRNA upon LINC0I089 overexpression. Mean \pm SD, $n=3$, $* P<0.05$, $* * P<0.0 I$, and $* * * P<0.001$.

Abbreviation: RT-qPCR, quantitative real-time polymerase chain reaction.

CDK6, which specifically bind to and are activated by D-type cyclins (such as cyclin D1, cyclin D2 and cyclin D3), facilitate the transition from $\mathrm{G} 0 / \mathrm{G} 1$ to $\mathrm{S}$ phase. ${ }^{28}$ Our results indicated that LINC01089 inhibited BC cell proliferation, and the cell percentage of $\mathrm{G} 0 / \mathrm{G} 1$ phase increased upon ectopic expression of LINC01089. Western blots showed decreased expression levels of cyclin D1, CDK4, and CDK6 in cells overexpressing LINC01089, which confirmed our observations in the cell proliferation assays. Therefore, the underlying mechanism by which LINC01089 inhibits BC cell proliferation most likely involves suppressing the activity of D-type cyclin-CDK4/6 complexes and subsequently inducing G0/G1 phase arrest.

Sas-Chen et al found that EGF downregulated LIMT/ LINC01089 in MCF-10A cells, and the cell numbers of migration were significantly increased in response to EGF treatment following LIMT knockdown in MCF-10A cells. ${ }^{17}$ Therefore, we asked whether EGF could reserve the effects of LINC01089 on BC cell proliferation, migration and invasion. Our results revealed that LINC01089-mediated partial inhibitory effects on $\mathrm{BC}$ cells were restored by EGF treatment. All these results showed that EGF could reverse partial biological functions of LINC01089 in BC cells.
Wnt/ $\beta$-catenin signaling plays crucial roles in tumorigenicity, metastasis and maintaining the stemness of stem cells. $^{29-31}$ Abnormal activation of canonical Wnt signaling promotes tumor growth and $\mathrm{BC}$ progression. ${ }^{8}$ For example, as shown in the study by Gao et al, PSAT1 directly targets and is activated by AFT4, thereby activating the $\mathrm{Wnt} / \beta$ catenin signaling pathway in ER-negative BC. ${ }^{32}$ Periostin recruits Wnt1 and Wnt3a, enhancing Wnt signaling and increasing stem cell maintenance and metastasis in $\mathrm{BC}^{33}$ According to Yang et al, LGR5, an adult stem cell marker, regulates $\mathrm{CSC} /$ tumor-initiating cell renewal in $\mathrm{BC}$ by activating $\mathrm{Wnt} / \beta$-catenin signaling. ${ }^{34} \beta$-Catenin, a major component of Wnt signaling, is a strong independent prognostic factor in BC. ${ }^{10}$ In our investigation, LINC01089 overexpression reduced the levels of total $\beta$-catenin, active $\beta$-catenin

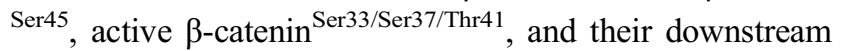
targets, including cyclin D1 and c-Myc. Moreover, as determined using RT-qPCR, $\beta$-catenin mRNA levels were dramatically decreased in LINC01089-overexpressing cells. Hence, we speculated that LINC01089 may have a negative impact on $\beta$-catenin transcription. Taken together, the data indicate that LINC01089 inhibits Wnt/ $\beta$-catenin signaling 
via the transcriptional downregulation of $\beta$-catenin. The specific mechanism linking LINC01089 and $\beta$-catenin transcription must be elucidated in future studies. We provide novel insights into the mechanism by which LINC01089 regulates $\beta$-catenin, thus improving our understanding of dysregulated $\mathrm{Wnt} / \beta$-catenin signaling in BC.

\section{Conclusion}

In summary, LINC01089 is significantly downregulated in $\mathrm{BC}$ and functions as a tumor suppressor. Its role as an independent prognostic factor in $\mathrm{BC}$ was verified. And $\mathrm{EGF}$ could reverse the partial effects of LINC01089 on BC cells. Mechanistically, LINC01089 blocked Wnt/ $\beta$-catenin signaling by inhibiting $\beta$-catenin transcription, thus suppressing BC cell proliferation, migration, and invasion. Based on these results, LINC01089 is potentially a novel prognostic indicator and therapeutic target, and this lncRNA is responsible for $\mathrm{BC}$ tumorigenicity and progression through a mechanism dependent on $\mathrm{Wnt} / \beta$-catenin signaling.

\section{Acknowledgments}

This research was supported by National Natural Science Foundation of China (No. 31420103915), The Scientific Research and Innovation Project of Chongqing (No. CYS17158).

\section{Disclosure}

The authors report no conflicts of interest in this work.

\section{References}

1. Siegel RL, Miller KD, Jemal A. Cancer statistics, 2019. CA Cancer J Clin. 2019;69(1):7-34. doi:10.3322/caac.21551

2. DeSantis CE, Ma J, Goding Sauer A, Newman LA, Jemal A. Breast cancer statistics, 2017, racial disparity in mortality by state. $C A$ Cancer J Clin. 2017;67(6):1-10. doi:10.3322/caac.21412

3. Schwartz RS, Erban JK. Timing of metastasis in breast cancer. $N$ Engl J Med. 2017;376(25):2486-2488. doi:10.1056/NEJMcibr1701388

4. Clevers H. Wnt/ $\beta$-catenin signaling in development and disease. Cell. 2006;127(3):469-480. doi:10.1016/j.cell.2006.10.018

5. Qi J, Yu Y, Öztürk ÖA, et al. New Wnt/ $\beta$-catenin target genes promote experimental metastasis and migration of colorectal cancer cells through different signals. Gut. 2016;65(10):1690-1701. doi:10.1136/ gutjnl-2014-307900

6. Holland JD, Klaus A, Garratt AN, Birchmeier W. Wnt signaling in stem and cancer stem cells. Curr Opin Cell Biol. 2013;25(2):254-264. doi:10.1016/j.ceb.2013.01.004

7. Nusse R, Clevers H. Wnt/ $\beta$-catenin signaling, disease, and emerging therapeutic modalities. Cell. 2017;169(6):985-999. doi:10.1016/j. cell.2017.05.016

8. Yu QC, Verheyen EM, Zeng YA. Mammary development and breast cancer: a wnt perspective. Cancers (Basel). 2016;8(7):1-26. doi: $10.3390 /$ cancers 8070065
9. Zhan T, Rindtorff N, Boutros M. Wnt signaling in cancer. Oncogene. 2017;36(11):1461-1473. doi:10.1038/onc.2016.304

10. Lin S-Y, Xia W, Wang JC, et al. B-catenin, a novel prognostic marker for breast cancer: its roles in cyclin D1 expression and cancer progression. Proc Natl Acad Sci. 2000;97(8):4262-4266. doi:10.1073/pnas.060025397

11. Beermann J, Piccoli M-T, Viereck J, Thum T. Non-coding RNAs in development and disease: background, mechanisms, and therapeutic approaches. Physiol Rev. 2016;96(4):1297-1325. doi:10.1152/ physrev.00041.2015

12. Bouckenheimer J, Assou S, Riquier S, et al. Long non-coding RNAs in human early embryonic development and their potential in ART. Hum Reprod Update. 2016;23(1):19-40. doi:10.1093/humupd/dmw035

13. Esteller M. Non-coding RNAs in human disease. Nat Rev Genet. 2011;12(12):861-874. doi:10.1038/nrg3074

14. Bhan A, Soleimani M, Mandal SS. Long noncoding RNA and cancer: a new paradigm. Cancer Res. 2017;77(15):3965-3981. doi:10.1158/ 0008-5472.CAN-16-2634

15. Gupta RA, Shah N, Wang KC, et al. Long non-coding RNA HOTAIR reprograms chromatin state to promote cancer metastasis. Nature. 2010;464(7291):1071-1076. doi:10.1038/nature08975

16. Mourtada-Maarabouni M, Pickard MR, Hedge VL, Farzaneh F, Williams GT. GAS5, a non-protein-coding RNA, controls apoptosis and is downregulated in breast cancer. Oncogene. 2009;28 (2):195-208. doi:10.1038/onc.2008.373

17. Sas-Chen A, Aure MR, Leibovich L, et al. LIMT is a novel metastasis inhibiting lncRNA suppressed by EGF and downregulated in aggressive breast cancer. EMBO Mol Med. 2016;8(9):1052-1064. doi:10.15252/emmm.201606198

18. Cerami E, Schultz N, Larsson E, et al. The cBio cancer genomics portal: an open platform for exploring multidimensional cancer genomics data. Cancer Discov. 2012;2(5):401-404. doi:10.1158/21598290.CD-12-0095

19. Manuscript A. Integrative analysis of complex cancer genomics and clinical profiles using the cBioPortal. Sci Signal. 2014;6(269):1-34.

20. Debnath J, Muthuswamy SK, Brugge JS. Morphogenesis and oncogenesis of MCF-10A mammary epithelial acini grown in three-dimensional basement membrane cultures. Methods. 2003;30 (3):256-268.

21. Li Y, Huang J, Zeng B, et al. PSMD2 regulates breast cancer cell proliferation and cell cycle progression by modulating p21 and p27 proteasomal degradation. Cancer Lett. 2018;430:109-122. doi:10.1016/j.canlet.2018.05.018

22. Prosperi RJ, Goss KH. A Wnt-ow of opportunity: targeting the Wnt/ $\beta$-catenin pathway in breast cancer. Curr Drug Targets. 2010;11 (9):1074-1088.

23. Pohl SG, Brook N, Agostino M, Arfuso F, Kumar AP, Dharmarajan A. Wnt signaling in triple-negative breast cancer. Oncogenesis. 2017;6(4):1-12. doi:10.1038/oncsis.2017.14

24. Liang $\mathrm{K}, \mathrm{Hu} \mathrm{Q}$, Li $\mathrm{P}$, et al. JAK2-binding long noncoding RNA promotes breast cancer brain metastasis. J Clin Invest. 2017;127 (12):4498-4515. doi:10.1172/JCI91553

25. Liao XH, Wang JG, Li LY, et al. Long intergenic non-coding RNA APOC1P1-3 inhibits apoptosis by decreasing $\alpha$-tubulin acetylation in breast cancer. Cell Death Dis. 2016;7(138):e2236. doi:10.1038/ cddis.2016.142

26. Wu W, Chen F, Cui X, et al. LncRNA NKILA suppresses TGF- $\beta$ induced epithelial-mesenchymal transition by blocking NF- $\mathrm{BB}$ signaling in breast cancer. Int $J$ Cancer. 2018;143(9):2213-2224. doi:10.1002/ijc. 31605

27. Malumbres M, Barbacid M. To cycle or not to cycle: a critical decision in cancer. Nat Rev Cancer. 2001;1(3):222-231. doi:10.1038/35106065

28. Lim S, Kaldis P. Cdks, cyclins and CKIs: roles beyond cell cycle regulation. Development. 2013;140(15):3079-3093. doi:10.1242/ dev.091744 
29. Yang S, Liu Y, Li MY, et al. FOXP3 promotes tumor growth and metastasis by activating Wnt/ $\beta$-catenin signaling pathway and EMT in non-small cell lung cancer. Mol Cancer. 2017;16:1. doi:10.1186/ s12943-017-0700-1

30. Ma Y, Yang Y, Wang F, et al. Long non-coding RNA CCAL regulates colorectal cancer progression by activating Wnt/ $\beta$-catenin signalling pathway via suppression of activator protein $2 \alpha$. Gut. 2016;65 (9):1494-1504. doi:10.1136/gutjnl-2014-308392

31. Zaribafzadeh H, Counter CM, Virshup DM, Hemmerich A, Kabiri Z, Greicius G. Wnt signaling suppresses MAPK-driven proliferation of intestinal stem cells. J Clin Invest. 2018;128(9):3806-3812. doi:10.1172/JCI99325
32. Gao S, Ge A, Xu S, et al. PSAT1 is regulated by ATF4 and enhances cell proliferation via the GSK3 $\beta / \beta$-catenin/cyclin D1 signaling pathway in ER-negative breast cancer. J Exp Clin Cancer Res. 2017;36 (1):179. doi:10.1186/s13046-017-0648-4

33. Malanchi I, Santamaria-Martínez A, Susanto E, et al. Interactions between cancer stem cells and their niche govern metastatic colonization. Nature. 2012;481(7379):85-91. doi:10.1038/nature 10694

34. Yang L, Xie X, Tang H, et al. LGR5 promotes breast cancer progression and maintains stem-like cells through activation of wnt $/ \beta$-catenin signaling. Stem Cells. 2015;33(10):2913-2924. doi:10.1002/ stem.2083
OncoTargets and Therapy

\section{Publish your work in this journal}

OncoTargets and Therapy is an international, peer-reviewed, open access journal focusing on the pathological basis of all cancers, potential targets for therapy and treatment protocols employed to improve the management of cancer patients. The journal also focuses on the impact of management programs and new therapeutic
Dovepress

agents and protocols on patient perspectives such as quality of life, adherence and satisfaction. The manuscript management system is completely online and includes a very quick and fair peer-review system, which is all easy to use. Visit http://www.dovepress.com/ testimonials.php to read real quotes from published authors. 